IP Periodica Polytechnica

Transportation Engineering

46(4), pp. 179-184, 2018

https://doi.org/10.3311/PPtr.12131

Creative Commons Attribution (i)

RESEARCH ARTICLE

\section{Legal Aspects Concerning Use of Drones in the Conditions of the Slovak Republic within the Sphere of Intra-logistics}

\author{
Gabriel Fedorko $^{1^{*}}$, Vladimíra Žofčinová ${ }^{2}$, Vieroslav Molnár ${ }^{1}$ \\ Received 14 December 2017; accepted 22 February 2018
}

\begin{abstract}
The use of drones for material transmits or support of activities of intra-logistics belongs among the new and progressive technological methods. Their primary purpose does not lie in the monitoring of employees; for the most part, it is utilized in the sphere of transport, when monitoring objects and private land properties or when supporting of intra-logistics, which is its primary economic purpose. Individual entrepreneurs need to protect their widely delineated private complexes which are always busy and full of employees. That is why they are often interested in eliminating of monitoring complexity of these areas. Newly proposed drone use requires further attention not only from the technical sphere but also from the field of law. Our current legal frame should be amended and updated as such, that it would enable their use.
\end{abstract}

\section{Keywords}

legal aspects, monitoring, drones, supply, intra-logistics

\footnotetext{
${ }^{1}$ Institute of Logistics,

Faculty of Mining, Ecology, Process Control and Geotechnologies,

Technical University of Košice,

04384 Košice, Park Komenskeho 14, Slovak Republic

${ }^{2}$ Department of Public Law,

Faculty of Public Administration,

Košice Pavol Josef Safarik University,

04001 Košice, Popradská 66, Slovak Republic

*Corresponding author, e-mail: gabriel.fedorko@tuke.sk
}

\section{Introduction}

The agenda of intra-logistics covers a vast scale of enterprise activities. Their primary task is, among others, to efficiently transfer given cargo to a given spot within the production hall, enterprise complex or stock room. The entrepreneurs, of course, strive to run activities connected to such transfer in a way that the operating costs would be lower than the costs of this performance. As a result, new progressive technologies have been put in use within the sphere of intra-logistics, and their application possibilities are being explored. One of such high -perspective intralogistics technologies are unmanned aerial vehicles -drones.

The word drone is of homonymous nature, one of its senses stands for naming unmanned aerial vehicle, in short-UAV (Unmanned Aerial Vehicles). (Chamberlain, 2017; Sandvik and Jumbert, 2016). Nowadays, the scale of their application is quite wide; they can be used for commercial or non-commercial purposes (Perritt and Sprague, 2015; Sandvik and Jumbert, 2016). Their original purpose- to take aerial pictures and videos is no longer so narrow as to restrict itself to these two tasks. Drones with temperature sensors can be used when searching an area to identify and save a wanted person, to monitor the actions of employees or animals in nature. Their cheap version is also utilized when creating sophisticated maps. Smith (2015) was examining the possibilities of its application in the sphere of monitoring of rivers flows. Possibilities of forest monitoring were introduced by Tiberiu et al. (2016). UAVs seem quite useful for weather monitoring (tracing of hurricanes). We cannot forget to mention the cheaper plants' monitoring (applying of fertilizers and pesticides) (Sánchez-Bou and López-Pujol, 2014). Drones are also found in the construction industry or in archaeology (for example when generating 3D models, when performing prophylactic checks on a construction or as a part of the maintenance of houses, roofs, and chimneys.) We cannot omit its important role as a part of marketing campaigns (billboards hanging on drones). The other sphere where drones were found quite useful is the sphere of army (defence against terroristic attacks, engaging drones when fighting a direct obstacle.)

From logistics aspect, development of UAV and their utilization when delivering smaller invoices within shorter 
distances (consignments, human blood) seem rather promising. Amazon, Google, and Zipline all have begun testing of this type of invoice delivery. However, great legislative or technical restrictions and issues related to their use still have not been fully removed. Recently, research on new types of drone control has developed, which resulted in the wide publishing of articles on the theme by numerous authors. Yu et al. (2014) have been analyzing possibilities in drone monitoring through eye movements. Rhee et al. (2012) have examined auto-piloting of drones by gyroscope and GPS. Autonomic navigation of drones was subject to study condemned by Ponnuswamy and Kumar (2017).

The issue of drone utilization, as already mentioned, requires engaging of intra-logistics. To enable its further development, however, we need to examine and analyze numerous spheres in a way that all obstacles which interfere with its application and slow it down will be eliminated efficiently. One such an area is our current legislative and its following legal aspects.

\section{Possibilities of Drones Utilization within the Sphere of Intra-logistics}

The idea of usage of drones of different compositions, types, and categories to perform various activities within the intra-logistics sphere of enterprises is not new. In general, these utilization possibilities can be divided into two main groups of critical fields. In the first one, their potential is used to perform various transporting and manipulating activities, while the other one engages drones in different inspection and evaluation activities.

\subsection{The Usage of Drones for Transporting and Manipulating Title}

Drones offer new perspectives regarding performing transfer and manipulating activities within the sphere of intra-logistics. They are, however, able to solve the issue of the system of invoices transport within numerous types of technological processes only hypothetically. This system has not been put in full use in the production sphere yet; the further research is still being carried out and, for the most part, this type of drone usage is still in the process of testing (Fig. 1).

The possibility of solving of transport issues only hypothetically results from the fact that in comparison with other conventional systems of transport, there are numerous risks and dangers related to drones utilization in this sphere. We have to, of course, take them into account. One issue arises when moving a cargo along the designated flight corridors. These flight corridors often overlap with the routes designed for employees' use. This issue should be dealt with from two points of views. The legislative aspect requires that current law regulations are amended so nothing would obstruct the usage of drones in branches of industry. The technical element deals with numerous types of questions, such as the question whether the flight corridors should be designed in a way that they would lead above employee's areas or their paths should be created above the isolated parts where employees are not allowed.

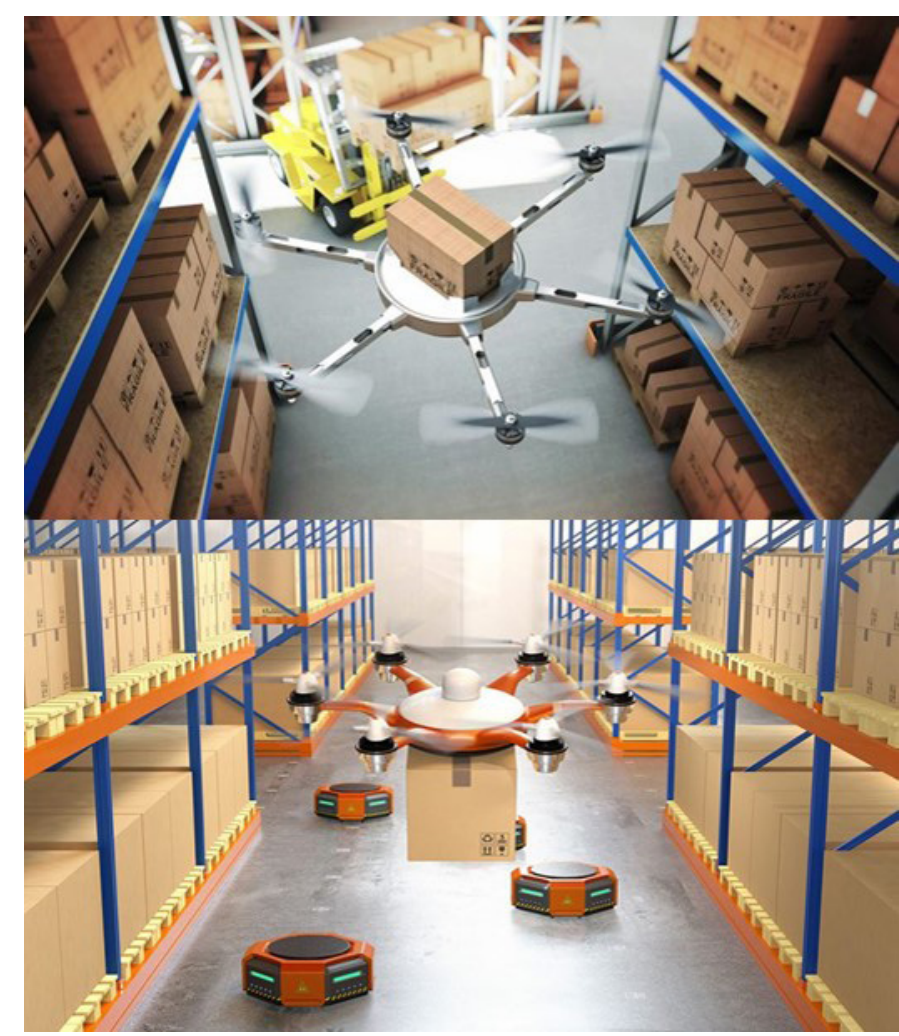

Fig. 1 Transfer of invoices with the help of drones in the sphere of intra-logistics ("https://www.mhisolutionsmag.com/wp-content/ uploads/2015/03/8888160.jpg" n.d.; "https://www.123rf.com/

photo_77950267_drone-and-orange-robots-in-modern-warehouse-advancedwarehouse-robotics-technology-concept-3d-render.html" n.d.).

\subsection{Drones as Means of Inspection and Evaluation}

The possibilities of drones' utilization in the sphere of inspection and evaluation are broad. We, again, can talk about the two primary areas, where they can be used. Firstly, they come useful when making inventories of stock in warehouses and outdoor premises. Secondly, they can be used in the sphere of inspection activities towards active and passive elements from the field of logistics. Last critical area is the issue of watching and monitoring of complexes, production halls, and warehouses. The crucial condition that has to be fulfilled to enable active usage of drones is the availability of suitable and sufficient monitoring technology, without which performing of such activities would not be possible. This monitoring technology has already been found. As an example, we shall list technology Eysee (Fig. 2).

\section{The Analysis of Legal Aspects concerning Drones Usage within the Conditions of the Slovak Republic}

In the Slovak Republic, the usage of drones is regulated by subsequent legal frame, which ensures that the competent legislature is able to inspect following of these regulations, it also empowers an employer and its users to use them. The regulation that guides their usage is Act No. 402/20013 Coll. 
on the Regulatory Authority for Electronic Communications and Postal Services and the Transport Authority and on the amendment of specific acts as amended (Act No. 402/20013 Coll. on the Regulatory Authority for Electronic Communications and Postal Services and the Transport Authority and on the amendment of specific acts as amended, n.d.).

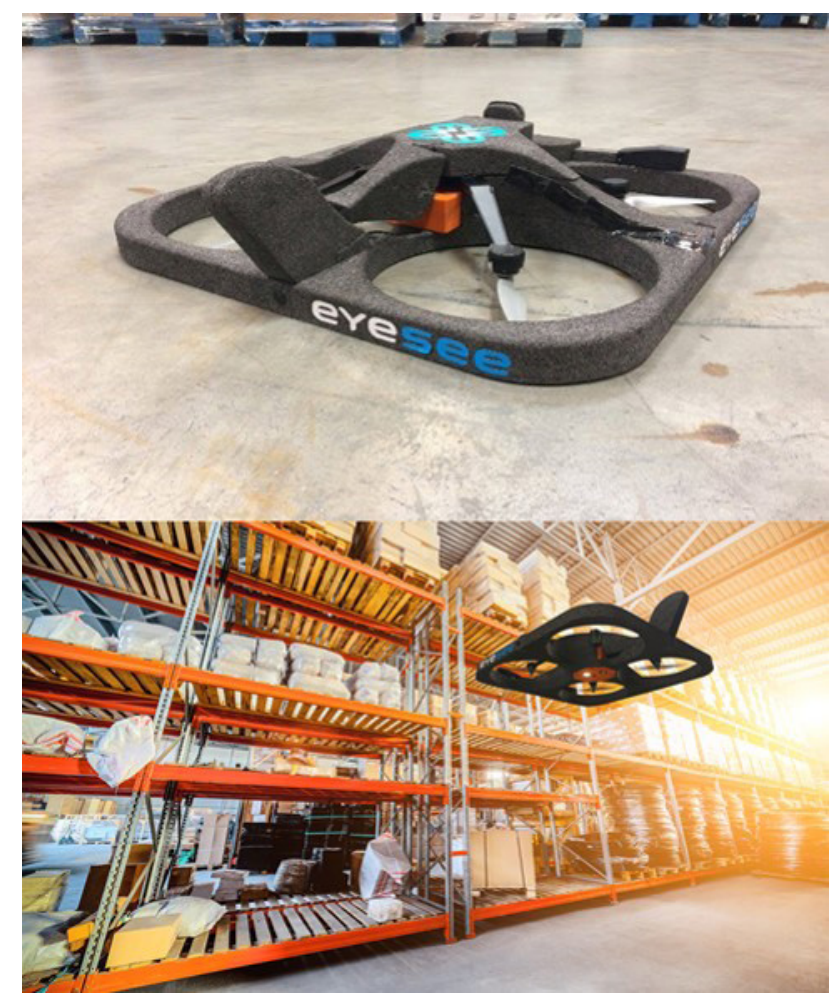

Fig. 2 Exemplification of Eysee system application in combination with drones within the sphere of intra-logistics ("https://i0.wp.com/eyesee-drone. com/wp-content/uploads/2017/11/incrustation2.png?zoom $=2.5 \&$ fit $=2953 \% 2 \mathrm{C}$ 1971\&ssl=1" n.d.; "https://i0.wp.com/eyesee-drone.com/wp-content/uploads/ 2017/11/23783859_155959588486526_1615082548989874815_o.jpg?zoom= $2.5 \&$ fit $=1224 \% 2 \mathrm{C} 918 \& \mathrm{ssl}=1 "$ n.d. $)$.

In compliance with the Section 8 of the mentioned Act, the Transport Authority, which would be a statutory body with the scope of application extended within the entire Slovak Republic and which would regulate the sphere of routes, civil aviation, and inland AIS shall be established. In accordance with the Section 48, Paragraph 1, Letter d) of the Act No. 143/1998 Coll. on Civil Aviation (Aviation Act) and on Amendments of Some Acts as amended by later regulations (hereinafter referred to as "the Act No. 143/1998 Coll.") (Act No. 143/1998 Coll, on Civil Aviation (Aviation Act) and on Amendments of Some Acts as amended by later regulations, n.d.), and according to the Section 7, Paragraph 2 to the Act No. 143/1998 Coll. and in compliance with the Annex II, letter i) of the of Regulation (EC) No. 216/2008 of the European Parliament and of the Council of 20 February 2008 on common rules in the field of civil aviation and establishing a European Aviation Safety Agency, by which Council Directive 91/670/EEC, Regulation (EC) No. 1592/2002 and Directive 2004/36/ES1 as amended (Regulation (EC) No.
216/2008 of the European Parliament and of the Council of 20 February 2008 on common rules in the field of civil aviation and establishing a European Aviation Safety Agency, n.d.) has been repealed and in compliance with the decision of the executive director of the European Aviation Safety Agency and following standards as well as recommendations from international organizations of civil aviation, which have been accepted by the Slovak Republic, the Transport Authority issued the decision 1 of 2015, by which it, as a relevant statutory body, described the conditions under which an auto-piloted aircraft can be flown in the airspace of the Slovak Republic.

This act more precisely defines the conditions for drones used in the airspace of the Slovak Republic. At this moment, we do not aim to analyze above-mentioned law regulation; we instead intend to draw the attention to some legal aspects, which can result from the practice of drones use when used by individual entrepreneurs at their operation premises respectively.

\subsection{Legislative Aspects of Drones Operation in Relation to Protection of Privacy and Security of Personal Data}

Monitoring is a fundamental aspect of the relationship between organizations, employees, and stakeholders and can affect perceptions of privacy, autonomy, and trust in the workplace (Fusi and Feeney, 2017). When protecting their ownership rights, employers are allowed to interfere with the privacy of their employees especially with the help of drones. Data collected from their camera memory can significantly intervene into the employee's natural fundamental rights. We cannot say that such form of controlling mechanism is found on the Slovak Labour Market quite usually, but at the same time, we cannot conclude that this type of inspection will not be used more and more in the future. Consequently, this could result in significant risks of rising violation of an employee's privacy. Employer- the operator can perform inspection and monitoring in various ways. Investigation of employees is a tool, which enables employers to monitor their employee while exercising of employer's rights has to be in the balance with employee's right for protection of their privacy. Employees can be subject to inspection only when there are serious reasons for such an inspection (such as protection of employer's ownership rights). It is, however, questionable, to what extent can such performance be classified as reasonable, and when we can already speak about intervention into the fundamental rights and freedoms of an employee, especially into their integrity. With the aim to protect their interests, namely economic aspirations, an employer often demands a right to intervene in employee's natural rights, when they can acquire information concerning their employee's private life. To set the borderline in compliance with the legal interests of both sides and to find acceptable solution taking into account protection of privacy given the current law code and legal sphere seems a somewhat laborious task. It is quite apparent, though, that right for protection of privacy of 
an employee established by the current Labour Code cannot be unrestricted, and its borderline must be set. On the other hand, the right of an employer to interfere with the natural rights of their employees and with their privacy too is not unlimited, and it has its purpose as well as legal limitations (Križan, 2016).

Within the meaning of Section 13, Paragraph 4 of the Act No. 311/2001 Coll. Of Labour Code (hereinafter referred to as Labour Code) (Act No. 311/2001 Coll. Of Labour Code, n.d.) "an employer is not allowed to intervene into the privacy of an employee at the workplace, as well as in conventional premises of employer by monitoring them without previous warning and without existence of serious reasons that would come from unique nature of their (employer's) activities". If an employer intends to introduce a controlling mechanism, they are obliged to discuss the extent of this monitoring, the way in which it should be performed as well as a term for which it should be implemented and employees' awareness of this tracking with relevant employees 'representatives. Subsequently, if an employer uses drones as one of the ways of monitoring, they will be obliged to fulfil subsequent regulations stated explicitly in the Labour Code. The imperative prohibition, binding each employer to act in a way as not to intervene into the privacy of an employee at their place of employment is spelt out in Section 13, Paragraph 4 of the Labour Code (Act No. 311/2001 Coll. Of Labour Code, n.d.). It is formulated as such that it restricts itself to the cumulative fulfilling of these two conditions:

a) An employee is willing to discuss the extent of such monitoring, a way in which it should be performed and term for which it should be conducted with subsequent employees' representatives.

b) An employer informs an employee about the extent of such inspection, about ways in which it should be performed and about the term for which it should be performed.

We are aware of the necessity to specify the way, process, time interval, the responsibility of people and conditions of whichever controlling mechanism, especially if an employer-operator began to use drones as controlling devices by internal legal regulations.

The wording of the Section 1 Paragraph 4 of the Labour Code (Act No. 311/2001 Coll. Of Labour Code, n.d.) in content agrees with new thinking solutions of the leading legal frame for protection of an employee's right for privacy, which is reflected in the Article 8 of Paragraph 1 of European Convention on Human Rights. It states that everybody is entitled to respect for its privacy and family life, respect for the place where they live and their correspondence. The principle mentioned above is contained in Article 19, Paragraph 2 of the Constitution of the Slovak Republic (the Article 19, Paragraph 3 to the Constitution) (Act No. 460/1992 Coll. Constitution of the Slovak Republic, n.d.) within the meaning of which everybody has a right for protection against unauthorized intervention into the private or family life. Similarly to that everybody has a right for protection from illegal collecting, publishing or another way of misuse of information about their person.

Constant case-law of European Court for Human Rights states that interference with the privacy of an individual has to be guided by three principles: by the principle of legality, the principle of legitimism and principle of proportionality. An employer's intent to monitor their employees by camera system (for example through the usage of drones), must originate from causes of serious nature (such as to use it as means of protection against alienation of existing assets) as this includes intervention into their right for privacy. Monitoring of employees should be sufficient, transparent and carried out for a specific purpose.

Another of legal aspects when using drones is intervention into the protection of private information. The initiator of pictures made by drone does often not realize or ignores the risks related to responsibility connected to use of these pictures, even though these pictures are taken by the external supplier as a part of the business relationship between the initiator and supplier. Although in cases stated above, the entrepreneurs shall not be held legally responsible for infringement of lawfully binding regulations in the sphere of civil aviation or area of protection of classified information (for example if drone usage had the character of so-called aerial work, which is a case when drones are used to take video recording within duration of flight), they always shall be held responsible for infringement of protection of private information. Those are the cases when these entrepreneurs decide about means used for processing of private information (drone that has invasive technology implemented inside) and about purposes for which they should be processed (for example use of mentioned video recordings for marketing purposes or data collection). (Fig. 3).

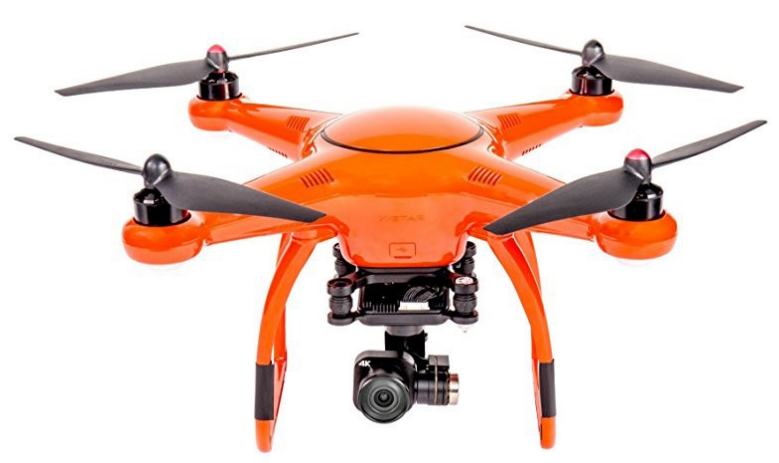

Fig. 3 Example of a drone that is meant for collecting and creation of video recordings within the sphere of intra-logistics ("https://images-na.ssl-imagesamazon.com/images/I/71KbetVv5IL__SY500_.jpg" n.d.)

If the video recordings display the marks according to which a person (an employee) can easily be identified, and they are of sufficient quality, the rule is that every entrepreneur-operatoremployer, who, within the meaning of Act No. 122/2013 Coll. On Personal Data Protection as amended (hereinafter referred to as Act on Personal Data Protection) (Act No. 122/2013 Coll. 
On Personal Data Protection as amended, n.d.) made a decision that a drone should have been used shall be considered as its operator and their (usually) supplier controlling the subsequent drone shall be, based on wording of above-mentioned act regarded as its supplier (of a drone) therefore, they shall be regarded as operator's intermediary. Even an assumption that mentioned video recordings made by drone are sufficient means enabling to identify the person in them even indirectly is seen as an adequate reason for applying Act on Data Protection. In case that previously mentioned happens in real life, the both of engaged subjects-operator and supplier (operator's intermediary) shall be obliged to make significant effort to eliminate legal and factual security risks. These are related to use of drone equipped with invasive technology that can result in violating of right for privacy of person being monitored as well as in breach of a public regulation establishing right for Personal Data Protection that, in the Slovak Republic, is mainly governed by the Act on Personal Data Protection and its implementing rules (Zimen, 2016). When using drones in civil life, it is necessary to protect privacy and personal data. To be able to do so, it is essential to draw our attention to the following principles, which, in short, reflect some of the main obligations of the operator as stated in Section 6, Paragraph 2 of the Act on Personal Data Protection (Act No. 122/2013 Coll. On Personal Data Protection as amended, n.d.):

- Principle of transparency towards the persons affected:

- Principle of legal use of drone;

- Principle of elimination and legitimism of purpose for personal data processing;

- Principle of proportionality related to processing of personal data;

- The principle of safety concerning processing of personal data.

\subsection{Legal Aspects concerning Drones Delivering Invoices of Various Categories}

Within the meaning of Section 38 of the Labour Code (Act No. 311/2001 Coll. Of Labour Code, n.d.) "Employer's documents concerning the commencement, change or termination of employment or the commencement, change or termination of an employee's obligations under the employment contract must be delivered to the employee into his or her own hands. The employer shall deliver the document to the employee in the workplace, at his or her home, or anywhere the employee may be reached. If such delivery is impossible, the document may be delivered by postal company as registered mail."

An employee is delivered all documents subject to the Section 38 of the Labour Code provision (Act No. 311/2001 Coll. Of Labour Code, n.d.) from their employer by hand, which means that the materials being delivered cannot be accepted by any other person but the addressee. The Section 38 of the Subsequent provision of the Labour Code (Act No. 311/2001 Coll. Of Labour
Code, n.d.) explicitly names only two ways of by hand delivery: direct delivery (in person) or delivery performed by mailing company. Labour Code does not allow for electronic delivery or any other way of delivery besides the two named above. That is why we are pondering the hypothetical possibility of performing delivery services by drones. We noticed the existence of remarks referring to experiences regarding drone piloting.

If Labour Code of the Slovak Republic strives to be a modern legal act, it will be compelled to respond to actual social needs as well as to the apparent technological progress that is visible everywhere.

\section{Conclusion}

The use of drones has its perspective also in the Slovak Republic. The development of science and technology, new technological procedures and devices among which we classify hands free aircrafts- drones progresses somewhat dynamically. As Horváthová et al. (Horváthová et al., 2017) have it, within the global and marketing environment in the sphere of cross-border commerce and cooperation, the competition level in between enterprises in so-called economic regions such as European Union has risen. Regarding this, the use of new technological devices such as drones generates the space for natural competition between firms, enterprises, and operating premises. The legislative environment of the Slovak Republic seems, however, rather unprepared for such progress and it should be remembered that it hangs behind. The previously mentioned raises the question of whether the law remains an important avenue to delineate boundaries for worker surveillance (Ajunwa et al., 2017).

We have to conclude that given the conditions of the Slovak law system, the legal use of drones for civil or commercial purposes appears to be rigid, administratively complicated and it calls for more flexible legal regulation. The regulation should be such that it would encourage the development of this progressive technology in the civil sector and, at the same time, it would set the specific legal frame, which would eliminate threats aimed at protection of privacy, personal data protection or public security. We exemplified the possibilities for the use of drones in the sphere of work performance, specifically they can be used as means of possible monitoring of employees when performing their job or as means of delivering of employer's documents regarding the establishment of employment relationship, variation in its nature or its termination or the creation, changes made to or termination of an employee's duties resulting from employment contract. The operators- employers often only strive to satisfy their economic priorities, what may interfere with the protection of employee's rights. Operators that use drones to perform their business activities are bound to respect legislative principles and natural rights of an employee and to act accordingly. Internal legislative of employers should take into account the use of New Technologies. It also should guide and regulate the ways of its usage; responsibility of people 
engaged in this activity as well as it should define the procedures that would prevent infringement of legislative principles.

\section{Acknowledgement}

This work is a part of these projects by VEGA 1/0063/16, VEGA 1/0403/18, KEGA 018TUKE-4/2016, APVV 17-0235.

\section{References}

Act No. 122/2013 Coll. On Personal Data Protection as amended.

Act No. 143/1998 Coll, on Civil Aviation (Aviation Act) and on Amendments of Some Acts as amended by later regulations.

Act No. 311/2001 Coll. Of Labour Code.

Act No. 402/20013 Coll. on the Regulatory Authority for Electronic Communications and Postal Services and the Transport Authority and on the amendment of specific acts as amended.

Act No. 460/1992 Coll. Constitution of the Slovak Republic.

Ajunwa, I., Crawford, K., Schultz, J. (2017). Limitless worker surveillance. California Law Review. 105(3), pp. 735-776. https://doi.org/10.15779/Z38BR8MF94

Fusi, F., Feeney, M. K. (2017). Electronic monitoring in public organizations: evidence from US local governments. Public Management Review. https://doi.org/10.1080/14719037.2017.1400584

Horváthová, Z., Shishkin, A., Galanov, V. (2017). Managing Foreign Direct Investments: the Role of Crowding Out Effect. Polish Journal of Management Studies. 15(2), pp. 93-99. https://doi.org/10.17512/pjms.2017.15.2.09

https://www.mhisolutionsmag.com/wp-content/uploads/2015/03/8888160.jpg. (n.d.).

https://www.123rf.com/photo_77950267_drone-and-orange-robots-inmodern-warehouse-advanced-warehouse-robotics-technology-concept3d-render.html. (n.d.).

https://i0.wp.com/eyesee-drone.com/wp-content/uploads/2017/11/23783859 155959588486526_1615082548989874815_o.jpg?zoom=2.5\&fit=1224 $\% 2 \mathrm{C} 918 \& \mathrm{ssl}=1$. (n.d.).

https://i0.wp.com/eyesee-drone.com/wp-content/uploads/2017/11/ incrustation2.png?zoom=2.5\&fit=2953\%2C1971\&ssl=1. (n.d.).

https://www.amazon.com/Autel-Robotics-X-Star-Premium-1-2-Mile/dp/ B01B1H8322. (n.d.).

Chamberlain, P. (2017). Drones and Journalism: How the Media is Making Use of Unmanned Aerial Vehicles. Routledge, London. https://doi.org/10.4324/9781315618470

Križan, V. (2016). Ochrana súkromia zamestnanca v ére internetu. (Protection of employee privacy in the ere of Internet.) In: Barancová, H., Olšovská, A. (eds.), Súčasný stav a nové úlohy pracovného práva. (The present state and new tasks of labour law.) pp. 260-273. Praha. [online] Available from http://publikacie.iuridica.truni.sk/wp-content/ uploads/2017/02/Súčasný-stav-a-nové-úlohy-pracovného-práva.pdf [Accessed: 2nd February 2018] (in Slovak)

Perritt, H. H., Sprague, E. O. (2015). Drones. Vanderbilt Journal of Entertainment \& Technology Law.

Ponnuswamy, D., Kumar, S. S. (2017). Design and realization of an energy efficient vision-based autonomous target tracking drone using LabVIEW. In: Proceedings of 2016 Online International Conference on Green Engineering and Technologies. IC-GET 2016. Coimbatore, India, Nov. 19, 2016. pp. 1-6. https://doi.org/10.1109/GET.2016.7916707

Regulation (EC) No. 216/2008 of the European Parliament and of the Council of 20 February 2008 on common rules in the field of civil aviation and establishing a European Aviation Safety Agency.
Rhee, I., Cho, S., Park, S., Choi, K. (2012). Autopilot design for a target drone using rate gyros and GPS. International Journal of Aeronautical and Space Sciences. 13(4), pp. 468-473. https://doi.org/10.5139/IJASS.2012.13.4.468

Sandvik, K. B., Jumbert, M. G. (2016). The Good Drone. Routledge, London. https://doi.org/10.4324/9781315553405

Sánchez-Bou, C., López-Pujol, J. (2014). The coming revolution: The use of drones in plant conservation. Collectanea Botanica.

Smith, K. W. (2015). The Use of Drones in Environmental Management. World Environmental and Water Resources Congress. pp. 1352-1361. https://doi.org/10.1061/9780784479162.133

Banu, T. P., Borlea, G. F., Banu, C. (2016). The Use of Drones in Forestry. Journal of Environmental Science and Engineering B. 5(11). https://doi.org/10.17265/2162-5263/2016.11.007

Yu, M., Lin, Y., Wang, X., Schmidt, D., Wang, Y. (2014). Human-Robot Interaction Based on Gaze Gestures for the Drone Teleoperation. JEMR. 7(4), pp. 1-14.

https://doi.org/10.16910/jemr.7.4.4

Zimen, O. (2016). Využívanie dronov na civilné účely z pohl'adu ochrany osobných údajov. (Use of drons for civil purpose in term of personal data protection.) [online] Available from https://www.pravnenoviny. sk/obcianske-pravo/vyuzivanie-dronov-na-civilne-ucely-z-pohladuochrany-osobnych-udajov [Accessed: 2nd February 2018] (in Slovak) 